\title{
Improving Building Performance through Integrating Constructability in the Design Process
}

\author{
Ayman Ahmed Ezzat Othman \\ Architectural Engineering Department, \\ Faculty of Engineering, the British \\ University in Egypt, Egypt \\ aaeothman@gmail.com
}

THE TRADITIONAL PROCUREMENT APPROACHES COMMONLY ADOPTED IN CONSTRUCTION PROJECTS AND THE INVOLVEMENT OF MULTITUDE OF VARIOUS PROJECT PARTICIPANTS WITH DIVERSE OBJECTIVES, SKILLS AND INTERESTS TENDED TO SEPARATE DESIGN FROM CONSTRUCTION. This separation obstructs contractors from providing designers with construction feedback and suggestions for design improvement, which ultimately hampers the improvement of building performance. Because of the importance of the design phase and the vital role played by contractors in the construction industry, this paper aims to investigate the integration of construction knowledge and contractor's experience in the design process as an approach for improving building performance. In order to achieve this aim, a research methodology is designed to accomplish four objectives. Firstly, reviewing the nature of the construction industry; constructability; architecture and the design process and measuring building performance. Secondly, presenting case studies of successful projects benefited from applying the concept of constructability during the design process. Thirdly, developing an innovative framework to facilitate the integration of construction knowledge and contractor's experience in the design process and establishing the strategies that support its application. Finally, summarising research conclusions and recommendations useful to construction professionals and further research. Findings of the research showed that integrating the concept of constructability during the design process improves building performance (e.g. reducing construction time, cost and waste as well as improving quality and productivity) and enhances the relationships between project participants. The research adds a valuable contribution to the built environment body of knowledge through presenting a practical approach for integrating construction knowledge and contractor's experience in the design process. 
Keywords

constructability, design

management, design process, partnering, performance, quality.

\section{INTRODUCTION}

The construction industry is one of the biggest industries worldwide. It has significant contributions towards social and economic development at national and international levels. It provides communities with places for housing, education, culture, health care, business, leisure and entertainment. In addition, it constructs the infrastructure projects that are essential for these facilities to perform their intended functions. Furthermore, it increases the gross domestic product (GDP), motivates development of other industries that support the construction process such as building materials and construction equipment as well as offers employment opportunities. On the other hand, the construction industry is arguably one of the most resourceintensive and environmentally damaging industries worldwide. Construction accounts for $40 \%$ of the total flow of raw materials into the global economy every year. It is a substantial source of waste, pollution and land dereliction (Earth watch Institute 2011, Roodman and Lenssen 1995). Anink et al. (1996) stated that the construction sector is responsible for $50 \%$ of material resources taken from nature, $40 \%$ of energy consumption and $50 \%$ of total waste generated. Virtually, all modern buildings now have artificial heating or cooling systems and sometimes both. Large amounts of energy are wasted in constructing, heating and cooling large and impressive glass cladding skyscrapers particularly in sunny, hot and humid countries (Architectural Review 1995, Abdellatif and Othman 2006). Furthermore, the construction industry is plagued with a number of problems that limits achieving its optimum output. One of these important problems is the creation of division between designers and contractors through separating design from construction (Field and Ofori 1988, Othman 2007, Mthalane et al. 2008). The traditional procurement approaches usually used in construction projects and the large number of organisations, with different and sometime conflicting objectives, skills and interests took part in creating a fragmentation and adversarial relationship between project participants, which eventually obstructed contractors from providing designers with construction comments and feedback to improve the building design (Motsa et al. 2008). Professional fragmentation in construction has become the theme of many research studies carried out globally. This has triggered the emergence of the concepts of 'Buildability' and 'Constructability'. Although both terms are used interchangeably, buildability refers to the extent to which a building design facilitates ease of construction whilst other clients' requirements are met. It focuses on the design of a building. In contrast, constructability, which embraces both design and management functions, is concerned with a wider scope than 'buildability'. It deals with the project management systems that optimally use construction knowledge and experience to enhance efficient project delivery. Particularly, benefits become apparent when constructability is considered at the earliest possible stages (Wong et al. 2006). The importance of the design process as many critical decisions are made during this phase (e.g., material selection, standard components, construction methods) and the key role played by contractors as the entity responsible for delivering the designed facility, called for the early involvement of contractors in the design process as an approach for improving building performance.

\section{Research aim and objectives} The aim of this paper is to investigate the integration of construction knowledge and contractor's experience in the design process as an approach for improving building performance. In order to achieve this aim, four objectives have to be accomplished: 
- Building a thorough background of the study topic through reviewing the state-of-the-art relating to the nature of the construction industry; constructability; architecture and the design process and measuring building performance.

- Presenting a number of case studies of successful projects improved their performance through integrating construction knowledge and contractor's experience in the design process.

- Developing an innovative framework to facilitate the integration of construction knowledge and contractor's experience in the design process and establishing the strategies that support its application.

- Outlining the research conclusions and recommendations useful for construction professionals and further research.

\section{Research methodology}

The research methodology designed to achieve the abovementioned aim and objectives, consisted of three interrelated activities, namely data collection, data analysis and action required. During the data collection activity, different sources are used to accomplish the first and second objectives. This included textbooks, academic journals, conference proceedings, dissertations and thesis, government publications and related websites. In addition, creative case studies of successful projects are presented to show the benefits of integrating construction knowledge and contractor's experience during the design process. They included the re-design of the structural system of Lansing Community College, Michigan, USA and the integration of contractor in the design of Cannon beach residence project Oregon, USA. Collected data was analysed qualitatively through focusing on the contractor's contribution, methods and timing of integration during the design process. As an action for facilitating the integration of the concept of constructability in the design process as an approach for improving building performance, an innovative framework is developed and the strategies that support its application are established. Because of the importance of validity and reliability, this research depended on facts rather than subjective information which increased the reliability and validity of collected data and research findings.

\section{Literature review}

\section{The Nature of the Construction Industry}

The construction industry is a dynamic and ever-expanding business. It plays a significant role towards supporting governments and international organisations to achieve their social and economic development programmes. On the other hand and due to its nature, construction is a complex, risky, fragmented industry and has negative impacts to the environment. It is a time-consuming process that consists of thousand of interrelated design, construction and operation activities. Construction is characterised by high capital investment, reliance on developers and subcontractors, an extensive and complex regulatory framework, high interest costs and competition. In addition, increasing client expectations coupled with the technological development of materials and equipment as well as the impact of internal and external influences made the construction industry subject to more risks than any other industry (Othman et al. 2004, Othman and Harinarain 2009). Furthermore, the involvement of multitude of participants (e.g. clients, architects, engineers, contractors, labours) with different objectives, skills and interests coupled with the traditional procurement approach which separates design from construction and creates a division between designers and contractors, made the construction industry a highly fragmented business. This inhibited the design team from utilising and benefiting from the construction knowledge and experience of other project participants, particularly contractors. Hence, design mistakes, incompatible drawings, lack of details, inefficient construction methods, specification ambiguity and errors are repeated which obstruct improving building performance on the long run.

\section{Constructability \\ Definitions and Concept Development}

The Construction Industry Institute (CII 1987) defined Constructability as the optimum integration of construction knowledge and experience in planning, design, procurement, and field operations to achieve overall project objectives and improve building performance. Constructability, which is also known as Buildability in the UK, is a project management technique that encompasses a detailed review of design drawings, models, specifications, and construction processes by one or more highly experienced construction engineers or specialists, working with the project team before a project is put out for bids and also prior to construction mobilization (Douglas and Gransberg 2009). It helps identifying obstacles before a project is actually built to reduce or prevent errors, delays, wastes and cost overrun. Constructability focuses the team on maximizing the simplicity, economy, and speed of construction, while considering the site conditions, code restrictions, and client requirements (Aeck and Ruby 2006) which increases the probability of project success, reduce construction waste and improve building performance.

The concept of Constructability was first emerged in UK and USA during the late 1970's as a result of studies aimed to maximize the efficiency, productivity, cost effectiveness and quality in the construction industry. Researchers in the UK had initially focused their attention on the design process and the early involvement of construction expertise. 
Later on, researchers tended to enlarge the scope by encompassing management practices and procurement approaches as contributors to the buildability and constructability concepts. In the US, the CII promoted the concept of constructability and formulated guidelines for implementation. Likewise, CII Australia proposed 12 principles for putting the concept of constructability in action. In the 1990s, Singapore introduced the first assessment system for buildability of designs. These studies and actions showed that the lack of integration of construction knowledge into the design process was considered as one of the main reasons for projects exceeding their budgets and schedule deadlines (Trigunarsyah 2004, Wong et al. 2006).

\section{Constructability Concepts}

23 concepts have been developed by Nima et al. (2001) to enhance and facilitate the adoption and application of the constructability philosophy throughout the different phases of the construction process (see Tables 1, 2 \&3)

\section{Table 1: Constructability Enhancement Concepts during Conceptual Planning Phase}

Concept $\mathrm{C}_{1}$

Concept $\mathrm{C}_{2}$

Concept $\mathrm{C}_{3}$

Concept $\mathrm{C}_{4}$

Concept $\mathrm{C}_{5}$

Concept C6

Concept $\mathrm{C}_{7}$

The project constructability programme should be discussed and documented within the project execution plan, through the participation of all project team members.

A project team that includes representatives of the owner, engineer and contractor should be formulated and maintained to take the constructability issue into consideration from the outset of the project and through all of its phases.

Individuals with current construction knowledge and experience should achieve the early project planning so that interference between design and construction can be avoided.

The construction methods should be taken into consideration when choosing the type and the number of contracts required for executing the project.

The master project schedule and the construction completion date should be construction-sensitive and should be assigned as early as possible.

In order to accomplish the field operations easily and efficiently, major construction methods should be discussed and analysed in-depth as early as possible to direct the design according to these methods. This could include recovery and recycling methods as well as sustainable and final disposal planning.

Site layout should be studied carefully so that construction, operation and maintenance can be performed efficiently, and to avoid interference between the activities performed during these phases.

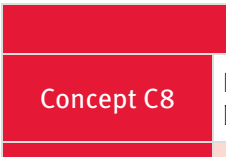

Table 2: Constructability Enhancement Concepts During Design and Procurement Phases

Design and procurement schedules should be dictated by construction sequence. Thus, the construction schedule must be discussed and developed prior to the design development and procurement schedule.

Concept $\mathrm{C}_{9}$

Concept $\mathrm{C}_{10}$

Concept $\mathrm{C}_{11}$

Concept $\mathrm{C}_{12}$

Concept $\mathrm{C}_{13}$

Concept $\mathrm{C}_{14}$

Concept $\mathrm{C}_{15}$

Advanced information technologies are important to any field including the construction industry. Therefore, the use of those technologies will overcome the problem of fragmentation into specialized roles in this field, and enhance constructability.

Designs, through design simplification by designers and design review by qualified construction personnel, must be configured to enable efficient construction. This will help minimise material waste, recycling and cost-effectiveness.

Project elements should be standardized to an extent that will never affect the project cost negatively.

The project technical specifications should be simplified and configured to achieve efficient construction without sacrificing the level or the efficiency of the project performance.

The implementation of modularization and preassembly for project elements should be taken into consideration and studied carefully. Modularization and preassembly design should be prepared to facilitate fabrication, transportation and installation.

Project design should take into consideration the accessibility of construction personnel, materials and equipment to the required position inside the site.

Design should facilitate construction during adverse weather conditions. Efforts should be made to plan for the construction of the project under suitable weather conditions; otherwise, the designer must increase the project elements that could be prefabricated in workshops.
} 

minimize scaffolding needs, formwork used, or congestion of construction personnel, material and equipment.

Innovation in temporary construction materials/systems, or implementing innovative ways of using available

Concept $\mathrm{C}_{17}$

Concept $\mathrm{C}_{18}$ temporary construction materials/systems that have not been defined or limited by the design drawings and technical specifications will contribute positively to the enhancement of constructability.

Incorporating innovation of new methods in using off-the-shelf hand tools, or modification of the available tools, or introduction of a new hand tools that reduce labour intensity, increase mobility, safety or accessibility will enhance constructability at the construction phase.

Concept $\mathrm{C}_{19}$

Introduction of innovative methods for using the available equipment or modification of the available equipment to increase their productivity will lead to a better constructability.

Concept $\mathrm{C}_{20}$

In order to increase the productivity, reduce the need for scaffolding, or improve the project constructability under adverse weather conditions, constructors should be encouraged to use any optional preassembly.

Concept $\mathrm{C}_{21}$

Constructability will be enhanced by encouraging the constructor to carry out innovation of temporary facilities.

Concept $\mathrm{C} 22$

Concept $\mathrm{C} 23$

Good contractors, based on quality and time, should be documented, so that contracts for future construction works would not be awarded based on low bids only, but by considering other project attributes, i.e. quality and time.

Evaluation, documentation and feedback of the issues of the constructability concepts should be maintained throughout the project to be used in later projects as lessons learned.

\section{Constructability Awareness and Reviews in Design Firms}

Two international studies by Arditi et al. (2002) in the United States and Motsa et al. (2008) in South Africa found that most design firms are aware and perceive the concept of constructability with $95.7 \%$ and $84 \%$ respectively. $50.7 \%$ of respondents in the United States indicated that they have a formalized corporate philosophy about constructability in their organizations. Where in South Africa, $76 \%$ of the design firms indicated that they required contractors' experience in their design because contractors have better knowledge about material availability and appropriate technology that affects design and cost. In their survey, Uhlik and Lores (1998) indicated that $90 \%$ of general contractors surveyed did not have formal constructability programmes, nor did they take action towards the implementation of constructability programmes. There seem to be more explicit constructability programmes in design firms than in construction companies. This is probably caused by the general belief that constructability review is particularly valuable in the design phase (Zimmerman and Hart 1982, Burati et al 1992).

\section{Techniques Used in Constructability Reviews}

There are a number of techniques used in construability reviews. Douglas and Gransberg (2009) mentioned in their study that "peer review" and "feedback systems" are the most popular tools used in conducting constructability reviews in design firms with $88 \%$ and $87 \%$, respectively (see Figure 1). This is because government authorities (e.g. the city of Boston) mandate peer reviews for specific contracts and before issuing building permits for complex projects. There are two types of peer reviews, namely project management and project design. The first focuses on the planning or management aspects of a project; whereas the latter evaluates the technical aspects of a project. Peer reviews may involve both of these reviews to

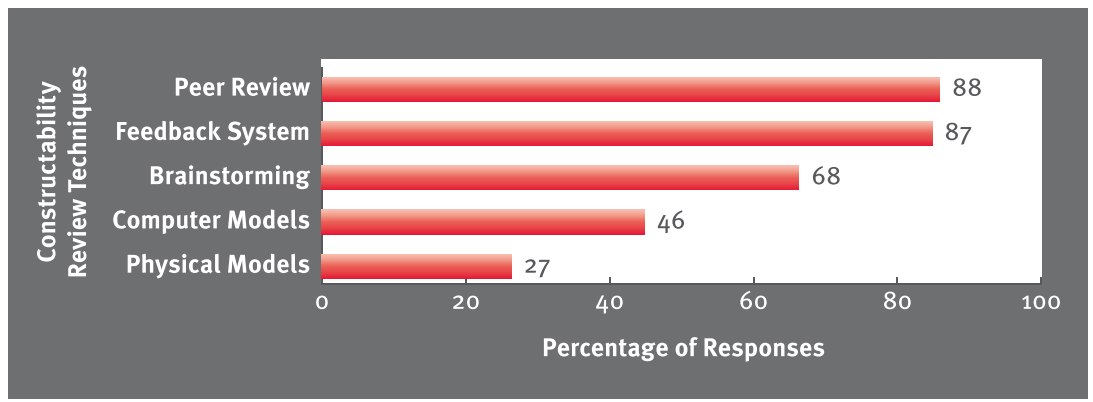

improve the quality of a project prior to entering the construction phase. A major advantage of peer reviews is benefitted from the accumulated construction experience to uncover and correct design inconsistencies and specify alternative construction methods that the designer may not be familiar with. The feedback process involves the capture and transfer of past lessons learned using either hard copy records or multimedia tools. In the latter, the computer tool captures, records, and stores constructability concepts and lessons learned, while providing design professionals with easy access and graphical retrieval of concepts and lessons to deepen their understanding of constructability issues (Multimedia Constructability Tool 1998 cited in Arditi et al. 2002). 
Small-scale physical models are considered the least common tool used in constructability analysis. This finding indicates that this once popular tool used to visualize the project is on its way to becoming obsolete except for highly sophisticated structures like petrochemical plants. Design firms appear to rely more on computer generated models to pursue constructability of design than building physical models, probably because of cost and time considerations. It is worth mentioning here that design firms utilize various different tools in their pursuit of constructability, depending on the characteristics of the projects undertaken. Other techniques included discussions with contractors, clients, and suppliers; quality assurance/quality control after each design stage; the construction manager participating in design reviews; and design checklist reviews.

\section{When to Apply Constructability Reviews?}

Because of its ability to improve building performance, constructability could be applied at any phase of the project life cycle. But due to the different nature of every phase in terms of the involved parties, technical requirements, inputs, tools and techniques as well as expected output, the potential contribution of constructability varies (see Table 4) (Douglas and Gransberg 2009)

\begin{abstract}
Table 4: Constructability Contributions During Project Phases
Project Phase $\quad$ Phase Characteristics and Constructability Contribution

Often clients of projects do not have any "in-house" capability for construction services, so they procure the services of a consulting firm to perform the initial "feasibility phase" constructability review. The consulting firm works from the preliminary design documents and provides useful suggestions (e.g., selecting sustainable and recyclable materials, reducing design complexity, etc.) that are incorporated into the design package. The focus of a feasibility phase constructability review is to generate alternatives that can be expanded by conceptual design decisions in a manner that permits the necessary financial and schedule considerations for each alternative to be determined with the requisite degree of certainty by cost engineering specialists or equivalent. Essentially, the constructability reviewer/consultant will furnish the client with options that were not contemplated by the designer. The results of the constructability review can literally make or break a project's viability.

As the architects/engineers develop the project design; the client typically retains a second team of specialists who specialize in providing construction management (CM) services. The constructability review takes place as the construction documents are being developed. This CM team will perform a detailed constructability review (CR) of the proposed project documents: design drawings, technical specifications including specified construction materials, the proposed site layout and if available; the construction cost estimate and project milestone schedule. This review effort will focus on whether the project can be built as designed. This CM/CR team effort will provide suggestions on ways to improve the project: such as a more efficient site layout, alternate construction materials including recycled ones, identifies possibly detrimental design specifications that could result in long lead time procurements or exotic construction techniques, using standard components as well as ease of design and disassembly.

When the overall project design is approximately $60 \%-90 \%$ complete, the client retains a construction management firm to prepare the project for the procurement phase that prepares the subcontracts and procurement bid packages, pre-qualification of vendors, suppliers and trade contractors. These procurement bid packages must be complete design packages in order to provide the qualified bidders with the information necessary to make intelligent cost proposals for the overall success of the project. During the subcontractor procurement process, after receipt of the request for proposal (RFP), the various bidding contractors will normally conduct their own constructability reviews prior to bidding. Constructability clarification questions are frequently transmitted to the client's representative who provides additional information about site conditions, ambiguous or missing construction details, and often the bidding contractors may propose alternate construction methods for consideration.

Constructability continues to be a viable tool for the success of the project after the award of the major contracts and purchase orders. For example, a mechanical contractor, employing constructability reviews, may determine that certain piping components could be fabricated in their shop and economically transported by truck to the project site, thereby improving both labour productivity and reduce the field costs for that large component of the work on a project. The client, the engineer, and the CM must remember that trade subcontractors are the technical experts in their field and must include construction contract language that encourages constructability improvement suggestions as well as requests for material and means substitutions. The submittal review process must be established to identify potential constructability improvements and then analyze the impact of implementing them on both project budget and schedule.

Constructability does not end when the project is completed. Often the project participants are in a hurry to close out

After Action Reviews the project and move on to another assignment. Either there is happiness over the success of the project, or there is a strong desire to put their bad experiences behind them and move on. In either case, there should be a formal review to capture the constructability lessons learned on the project. The corporation should establish a constructability database.
\end{abstract}


The integration of the concept of constructability throughout the project life cycle is supported by Arditi et al. (2002) who indicated that $87 \%$ of the surveyed design firms used constructability reviews during the developed design stage. In addition, Motsa et al. (2008) confirmed that $58 \%$ of South African design firms use constructability during the outline proposal stage and 50\% during the detailed proposal stage. This means that most design firms surveyed treat constructability integration as part of an overall continuous project improvement process, which is the recommended by most researchers (O'Connor and Miller 1994). Having another approach, Mendelsohn (1997) stated that it is generally believed that implementing constructability reviews should be conducted after plans are completed to a certain level in order for reviewers to have something to work with. Alternatively, construction knowledge and expertise must be brought in before any design is put onto paper. This approach enables designers to begin their work with certain key issues in mind, issues that can frequently be accommodated without adverse cost to the design.

\section{Professionals Involved in the Constructability Reviews}

Although achieving constructability objectives is the responsibility of all project participants, not all professionals have the same chance to be involved in the design process. Motsal et al. (2008) mentioned in their studies that, the surveyed design firms were asked to indicate the professionals that are usually involved in the design process. All respondents indicated that structural engineers were the most commonly involved professionals, while $44.7 \%$ of the respondents stated that specialist subcontractors were the least commonly involved (see Table 5). This could be attributed to the perception that some project participants can contribute more than others towards achieving constructability objectives. In addition, time constrains, client encouragement and participant's willingness could be other reasons to be considered.

\section{Constructability Reviews and Procumbent Methods}

There are a number of procurement methods used in construction projects namely traditional routes (e.g. designbid-build) and non-traditional routes

\begin{tabular}{|l|c|c|}
\hline \multicolumn{3}{|c|}{ Table 5: Professionals involved in the Constructability Reviews } \\
\hline Professionals & No. of respondents & $\%$ Response \\
\hline Quantity Surveyors & 36 & 94.7 \\
\hline Main Contractors & 18 & 47.4 \\
\hline Subcontractors & 18 & 47.4 \\
\hline Specialist Subcontractors & 17 & 44.7 \\
\hline Structural Engineers & 38 & 100 \\
\hline Electrical Engineers & 33 & 86.8 \\
\hline Mechanical Engineers & 33 & 86.8 \\
\hline Land Surveyors & 28 & 73.7 \\
\hline
\end{tabular}

\section{Construction Engineer's Involvement in Design}

Arditi et al. (2002) mentioned in their study that $95 \%$ of the respondents are of the opinion that construction engineers should be involved in the design phase in addition to other professionals that are already participating in this stage. This finding indicates that designers are aware of the need for a construction expert to provide the design team with insights into the construction phase of the project. Although $57 \%$ of the respondents believe that construction engineers should be involved regardless of project conditions, $38 \%$ indicated that the involvement of construction engineers should depend on the size, complexity, and type of project. Several respondents made remarks like "sometimes our office engineers do not see things as our construction people do". This kind of remark indicates that the designers are not against the potential advisory role that experienced construction personnel might play in their organizations. It emphasizes the fundamental differences between designers and contractors that a designer has a conceptual mind that relates to intangibles and a contractor has a practical mind that relates to tangibles. (e.g. design and build). Tam (2007) stated that the traditional procurement method is the most typical method used in the construction industry. One of the main burdens in using this method in construction projects is the lack of contractor involvement in the design stage. It should be noted that separation between designers and contractors in handling design and construction activities largely affects project constructability. The traditional procurement method lacks co-ordination between design and construction phases of the project, in which individual parties mainly concern on their own interests. Therefore, other procurement approaches are highly encouraged for construction projects to utilise the construction knowledge and contractor's experience to deliver better construction projects and develop common interests between project participants. An interviewed main contractor highlighted that the involvement of contractors at the early design stage in a project can bring advantages in considering construction methods (such as the use of prefabrication in major activities including concreting, plastering and formworking, rather than wet-trade 
construction activities) before project commencement on site and to improve project constructability.

\section{Barriers to Constructability}

O’Connor (1994) identified barriers to constructability as significant inhibitors that prevent effective implementation of a constructability programme. The barriers to constructability are (CII 1987, Abdellatif and Othman 2006, Douglas and Gransberg 2009).

\section{Owner Barriers}

- Lack of awareness and resistance to formal constructability programmes.

- Perception that constructability delays project schedule

- Reluctance to invest additional money and/or effort in early project stages

- Lack of genuine commitment

- Distinctly separate design management and construction management operations

- Lack of construction experience

- Lack of team-building or partnering

- Disregard of constructability in selecting contractors and consultants

- Contracting difficulties in defining constructability scope

- Misdirected design objectives and performance measures

- Lack of financial incentive for designer

- Gold-plated standard specifications

- Limitations of lump-sum competitive contracting

- Unreceptive to contractor innovation

\section{Designer Barriers}

- Perception that they have considered it.

- Lack of awareness of benefits, concepts, etc.

- Lacks of construction experience/ qualified personnel.

- Setting company goals over project goals.

- Lack of awareness of construction technologies.
- Lack of mutual respect between designers and constructors.

- Perception of increased designer liability.

- Construction input is requested too late to be of value.

- Faulty, ambiguous, or defective working drawings.

- Incomplete specifications and budgetary limitations.

\section{Contractor Barriers}

- Reluctance of field personnel to offer preconstruction advice.

- Poor timeliness of input.

- Poor communication skills.

- Lack of involvement in tool and equipment development.

\section{Waste Management and Recycling \\ Barriers}

- Lack of understanding the importance and benefits of managing and recycling waste,

- Lack of awareness and integration of the waste management philosophy in the design process.

- Not specifying the use of recycled materials in design.

- Over specification.

- Using materials / products that generate waste.

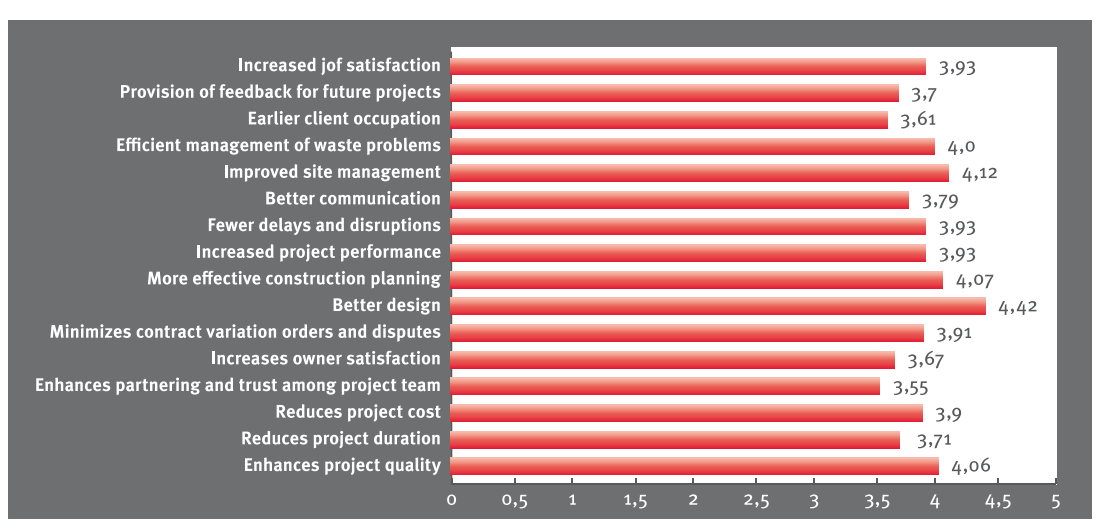

Figure 2: Benefits of Implementing Constructability

Table 6: The Opportunities for Implementing Constructability Reviews

\begin{tabular}{|l|l|}
\hline Developing better relationships with clients and contractors & 2.7 \\
\hline Being involved in fewer lawsuits & 2.5 \\
\hline Building a good reputation & 2.5 \\
\hline Professional satisfaction & 2.4 \\
\hline Efficient Design & 2.3 \\
\hline
\end{tabular}




\section{Architecture and the Design Process}

\section{Definitions}

By referring to Webster Dictionary, "Architecture" has one of the following meanings:

- The art of making plans for buildings, the work of an architect.

- The style or styles of building that an architect produces or imitates; as a church or modern architecture. It could be defined as the science and the art of building. It is understood to be the whole of the environment built by humans, including buildings, urban spaces, and landscape (Roth 1994).

The Architect is defined as the person who designs buildings. The role of the architect is to design buildings within the framework of the national building bylaws and the local planning restrictions and to document and supervise the erection thereof in order that it will meet the client requirements (Hauptfleisch 2004).

\section{An Introduction to Design}

Every construction project starts with a plan. The plan identifies all the details of the project. It is developed by many different people, such as architects, engineers, draughtsmen, and specification writers. Design is the first step in a construction project. It could be defined as "the process of deciding what a structure will look like and how it will function. Designing a project can be entirely new or it can be a result of several ideas combined together to meet the needs of a specific project (Fales 1991).

\section{Design Theories}

There are two opposing views of the theories of design. In one view, termed the "Glass Box Theory", design is taken to be a rational, explicable decision making process, while the opposing view, the "Black Box Theory", holds design ability to be a talent which cannot as yet be rationally explained. The "Glass Box Theory", assumes that the process is a transparent and rational one where objectives are fixed in advance, information relevant to the problem is gathered, this data is analysed, a possible solution is synthesised and then evaluated against the objectives. If it is thought that the attempt at the solution can be improved upon, then a re-iterative process follows where the solution is refined until some optimum is achieved. The "Black Box Theory" maintains that the most important part of the design process is the creative act on the part of the designer. They point out that the unpredictable, associative abilities of the human mind which produce an idea cannot be accounted for by any rational model. It is to this theory that many practising designers subscribe, they offend the attempts to explain their abilities and argue that designers cannot always give convincing reasons for their design decisions. Design problems are extremely complex, requiring the designer to deal interrelationship between many subproblems. When dealing with problems requiring the manipulation of more than one a few parameters then, the designer must initially focus on a wellstructured sub-problem as a point of entry to the design problem. The environment in which the design problem is being solved brings various pressures to bear on the designer. Principals among these pressures are lack of time and increasing professionalism. It is argued that architects gain more esteem from peer approval than from the satisfaction of the client or users. It is therefore in their interest at times to pursue their own aims in designing a building, particularly from the aesthetic point of view, and deny the client group the opportunity of interfering with his own ideas of how the building should be designed (Roth 1994, Othman 2008).

\section{The RIBA Plan of Work}

In 1964 the Royal Institute of British Architects (RIBA) published the RIBA Handbook in which was published a model procedure for methodical design process, termed the RIBA plan of Work. Subsequently, the plan of work was revised in 2000 and then updated in 2007 to cope with the ever-changing business environment, meet clients and users' expectations as well as technology enhancement. The process is typically broken down into 5 main phases namely, preparation, design, pre-construction, construction and use. Detailed description of the activities to be carried out in each phase is mentioned in Table 7 (RIBA 2011).

\section{Measuring Building Performance}

\section{Definitions and Background}

Generally speaking, performance is defined as the action or process of performing. Hence, measuring building performance could be defined as the evaluation of the ability of a building to accomplish its intended function and satisfy its users. It is an ongoing process which aims to identify what is going well and why and what is going wrong or could be improved, and why. In addition, corrective actions have to be taken in order to overcome shortcomings and enhance performance. Performance measurement can only be effective if it is carried out against specific aim and objectives (Pettinger 2001). In the past, the performance of construction projects was typically evaluated informally and in terms of cost, time, and quality. This type of evaluation was perhaps sufficient at that time because building projects were relatively less complex and the level of technology in design was low. But things have changed dramatically and the three categories of project evaluation of time, cost and quality have been described as insufficient. Building performance evaluation has to be improved to cope with the ever-increasing proliferation and specialisation in the construction industry in terms of building types, services, technology, code and regulatory requirements, energy conserva- 
(A) Appraisal

- Identification of Client's needs and objective, business case and of possible constraints on development.

- Preparation of feasibility studies to enable the client to decide whether to proceed.

Preparation $\quad$ (B) Design Brief

- Development of initial statement of requirements into the design brief by or on behalf of the Client confirming key requirements and constraints.

- Identification of procurement method, procedures, organisational structure and range of Consultants and others to be engaged for the Project.

(C) Concept

- Implementation of design brief and preparation of additional data.

- Preparation of Concept Design including outline proposals for structural and building services systems, outline specifications and preliminary cost plan.

- Review of procurement route.

(D) Design Development

Design - Development of concept design to include structural and building services systems, updated outline specifications and cost plan.

- Completion of Project Brief.

- Application for detailed planning approval.

(E) Technical Design

Preparation of Technical design(s) and specifications sufficient for co-ordination of all components and elements of the Project. and information for statutory standards and construction safety.

\section{(F) Production Information}

- F1 Preparation of detailed information for construction.

Application for statutory approvals.

- F2 Preparation of further information for construction required under the building contract. Review of information provided by specialists

Pre-Construction (G) Tender documentation

- Preparation and collation of tender documentation in sufficient detail to enable a tender or tenders to be obtained for the construction of the Project.

(H) Tender action

- Identification and evaluation of potential contractors and/or specialists for the construction of the Project.

- Obtaining and appraising tenders and submission of recommendations to the Client.

\section{(J) Mobilisation}

- Letting the building contract, appointing the Contractor.

- Issuing of production information to the Contractor.

Construction

- Arranging site handover to the Contractor.

(K) To practical completion

- Administration of the building contract up to and including practical completion.

- Provision to the Contractor of further information as and when reasonably required.

- Review of information provided by contractors and specialists.

(L) Post Practical Completion

- L1 Administration of the building contract after Practical Completion and making final inspections.

- L2 Assisting building user during initial occupation period

- L3 Review of project performance in use

tion, fire safety, environmental health, and safety constraints (Kagioglou et al. 2001, Langston and Ding 2001).

\section{Building Performance Criteria}

In order to improve building performance it is of prime importance to establish the criteria to be used for evaluating building performance. This will help design firms to utilise the construction knowledge and experience of project participants, contractors in particular, to achieve these criteria as an approach for improving building performance.
Building performance criteria could be carried out at three levels.

- Health, safety and security performance;

- Functional, efficiency and work flow performance;

- Psychological, social, cultural and aesthetic performance (Preiser and Vischer 2005).

\section{Benefits of Measuring Building Performance}

Although measuring building performance helps understanding current build- ing performance and end-users' requirements, it is an important tool for managing and planning for new facilities. The benefits of measuring building performance range from short term to long term (Barrett 1995).

\section{1) At the short-term}

Measuring building performance allows clients and facility management team to have a better understanding of the functionality and performance of their buildings compared with the stated criteria during design. In addition, active user 
participation in the evaluation process plays an important role in defining and considering their needs and requirements in the design of new buildings.

\section{2) At the medium-term}

The data collected during the assessment of building performance can be used as a source of knowledge for planning new buildings of similar type. Designers equipped with user feedback are helped to design future buildings that more closely meet the needs of the users.

\section{3) At the long term}

Measuring building performance helps establishing databases, generates planning and design criteria for specific building types and enables designers to consider documented past experience. This is important to avoid repeating past errors and recognise past success. The accumulated information plays a pivotal role in improving the quality of future buildings and services to the client and users. Assessment results may also improve design practice by making designers aware that their buildings may be subject of scrutiny. Thus design of future buildings may lead to better value for money to clients and society. This concern not only issues of functionality, but overall sustainability, energy efficiency and environmental impact.

\section{Case studies of successful projects benefited from integrating constructability in the design process The Lansing Community College, Michigan, USA}

Since the cost of the new campus building exceeded the allocated budget, Lansing Community College (LCC) decided to redesign the project or scrap part of it. LLC was established in 1957 to meet the growing demand for technical and specialized education in the Greater Lansing area, Michigan, USA. The LCC Health and Human Services Career Building was originally designed as a three story building with a future fourthfloor expansion. The expansion exceeded the $\$ 2.5$ million budget for steel fabrication and erection by $\$ 200,000$. Ruby and Associates Consulting Structural Engineers entered the project and applied the constructability principles to completely re-design the structural steel fabrication. Utilising their construction knowledge and the practical experience of Douglas Steel Fabrication Corporation, the re-design process included:

- Increasing the deck thickness from 2 " to 3" allowed the floor beams spacing to increase by 10 ". This reduced the number of floor beams by $78 \%$.

- Changing the mixed lateral load resisting system to moment frames in both directions and the connections were designed as field-bolted moment connections using the actual moments and stiffness required. This reduced field labour required and simplified shop fabrication.

- Reducing construction hours and labour needed for the structure through moving the fabrication from the field to the shop which enhanced the quality and increased work efficiency.
Using Information technology in communication and exchange of files and information reduced the re-design time and enhanced communication between different parties. The new design maintained design intent and made the project easier to build. 700 steel members and 1,400 connections were eliminated, while shear studs were reduced by 11,000 . Overall, approximately 300 tons of steel were saved. This saved enough money to enable LCC to construct the fourth floor upfront while bringing the project in approximately $\$ 100,000$ under budget and on schedule (see Figure 3) (Aeck and Ruby 2006).

\section{Cannon Beach Residence, Oregon,} USA.

The owners' request to the architect was for "a small home that will provide shelter, comfort, and rejuvenation." The request continued, "We will need for it to be equally comfortable when inhabited by just the two of us as when a gathering of family and friends joins us. Our new home should reflect the character of Cannon Beach and capture our love of mate-

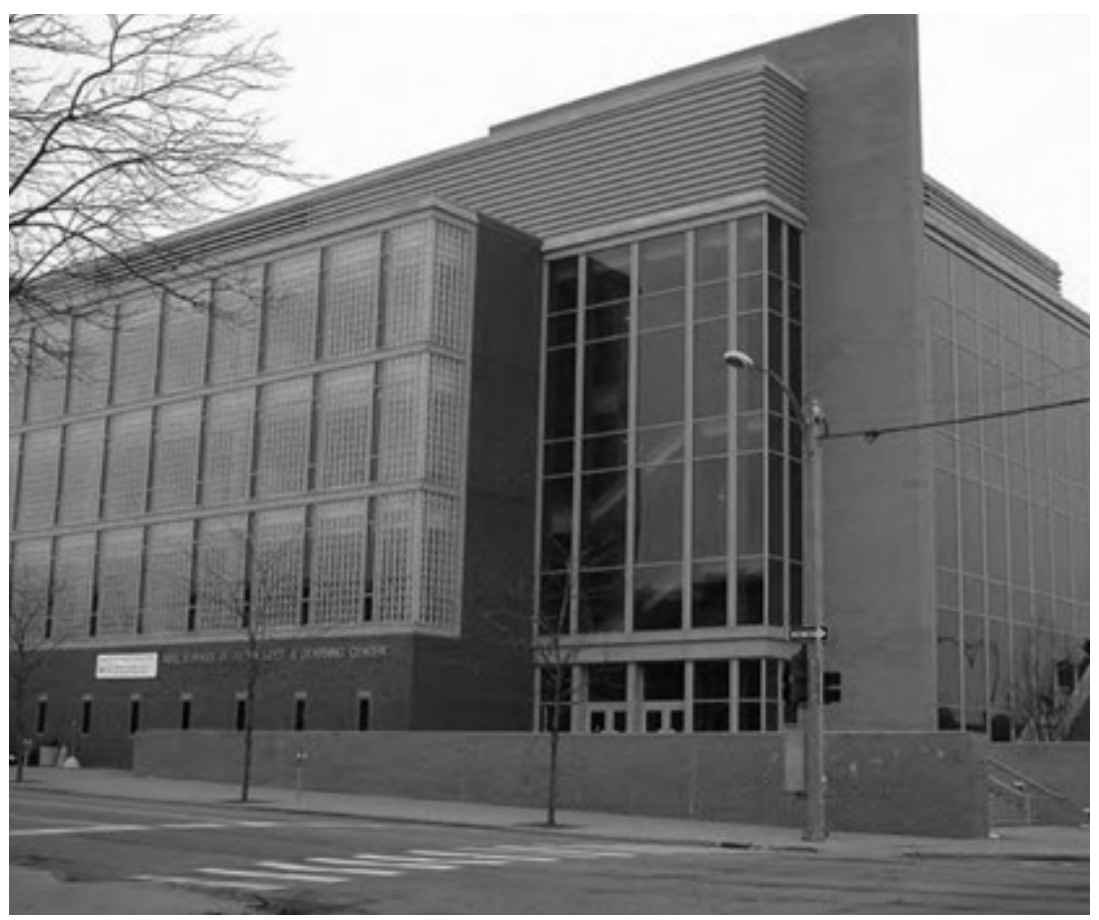

Figure 3: Applying constructability facilitates construction and reduces cost 


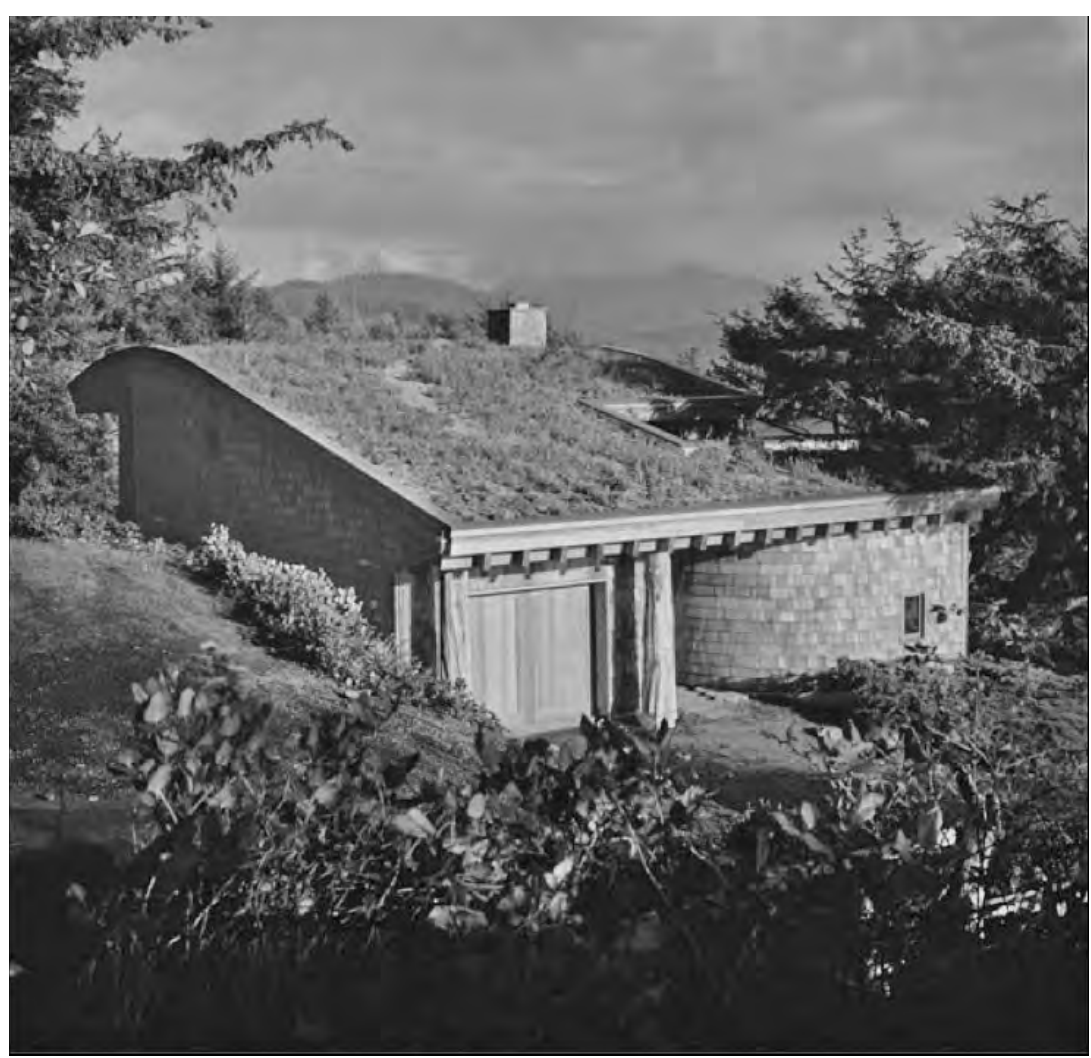

Figure 4: Early contractor involvement in design helps reducing life-cycle cost assessment, selecting sustainable materials and efficient building system (Home Design Home 2010).

rials and forms found in nature. We prefer for it to be low profile and understated. The home should be durable for generations and require little maintenance. Our goal is to build a home that is healthy to live in using materials and systems with a dramatically reduced impact on the environment." The project's integrated design team included the owners, architect, interior designer, and landscape architect. The contractor joined the team after schematic design was complete. The team held several meetings to establish clear and concise goals for the project (see Figure 4). During the design process, the project team conducted five half-day ecocharrettes, each composed of the core team, content experts, and guests of the owners, including artists, neighbours, and friends. Involving the contractor early in the design process was paramount, as the contractor contributed expertise to all aspects of the design process. The contractor's con-

ated life-cycle cost assessments was critical to the selection of building systems and materials. The contractor also contributed to the design for durability, low maintenance, reducing waste and longevity. Based upon the contractor's opinion that the local knowledge of green building was less than adequate to achieve the aggressive green goals for this project, the design team and owners conducted a six-hour greenbuilding seminar open to subcontractors, building officials, trades people, and the public (Cascadia 2009).

\section{Discussion}

Literature review and case studies showed that improving building performance could be accomplished through applying the constructability concept early in the project life cycle. The diverse experience of project participants (i.e. clients, architects, engineers, contractors, suppliers, etc.) represents a great opportunity to achieve the project objec- tives at the most cost-effective manner and in a way that saves the environment, enhances the society and prospers the economy. Being the entity responsible for constructing the designed facility, contractors have a significant role that could be played towards improving building performance during the design phase. As case studies showed, utilising construction knowledge and contractor's experience during the design phase, helped reducing cost, facilitating construction, reducing waste, resolving conflicts, reducing delays and selecting sustainable materials and better building systems. Contractors were involved in the early stages of the project life cycle and the peer review and feedback methods were adopted for constructability review. The main issue is how to make better utilisation and use of the involvement of project participants during the design stage. This necessitated the development of a framework that set the rules and establish the grounds that organise the involvement of construction professionals, contractors in particular, during the design stages as an approach for improving building performance.

\section{Improving building perform- ance framework (IBPF)}

\section{Definition and Justification of}

\section{Developing the Framework}

Framework is defined as a structure for describing a set of concepts, methods and technologies required to complete a product process and design (EDMS 2010). The Improving Building Performance Framework (IBPF) (hereinafter referred to as "the Framework" or the "IBPF") is a proposed framework developed by this research to facilitate the integration of construction knowledge and contactor's experience in the design process as an approach for improving building performance. The justification of developing the framework is a number of folds:

- Using natural resources and energy in an efficient way that reduces construction waste, reduces building 
and operating costs and enhances the reputation of the building industry.

- Improving building performance in terms of enhancing health, safety, security, function, efficiency, work flow, psychology, society and culture and aesthetic.

- Utilising the construction knowledge and contractor's experience to support the government initiatives towards achieving their strategies and plans for social and economic development.

- Enhancing the performance of organizations operating in the construction industry by creating partnership between project participants, especially designers and contractors.

- Adding value to the built environment and achieving customer satisfaction.

\section{The Aim and Objectives of the Framework}

The developed framework is a business improvement tool designed to integrate construction knowledge and contractor's experience in the design process as an approach for improving building performance. This aim could be achieved through accomplishing a set of interrelated objectives as follows:

- Identifying the problems that hinder integrating construction knowledge and contractor's experience in the design process.
- Establishing integration objectives.

- Developing integration plans.

- Executing integration plans.

- Monitoring / Optimising Integration.

\section{Description of the Framework}

The framework consists of five steps, namely: identifying integration problem, establishing integration objectives, developing integration plans, executing integration plans and monitoring / optimising integration (see Figure 5 ).

\section{Identifying integration problem}

The "Identifying Integration Problem" function is an essential activity of this framework because it enables design firms and construction professionals to identify the core causes that obstruct the integration of construction knowledge and contractor's experience in the design process. It is of importance to build an effective team (including a competent team leader) that will carry out the improvement study. Achieving a balance between the need for participants who represent various areas of expertise and possess diverse background is fundamental for accomplishing the study objectives. The study team should contain between six and twelve full time participants to maintain optimum productivity (Norton and McElligott 1995). Performing an early orientation meeting will help in establishing strategic issues like study duration, resources required and assigning responsibilities to team members. Senior management support

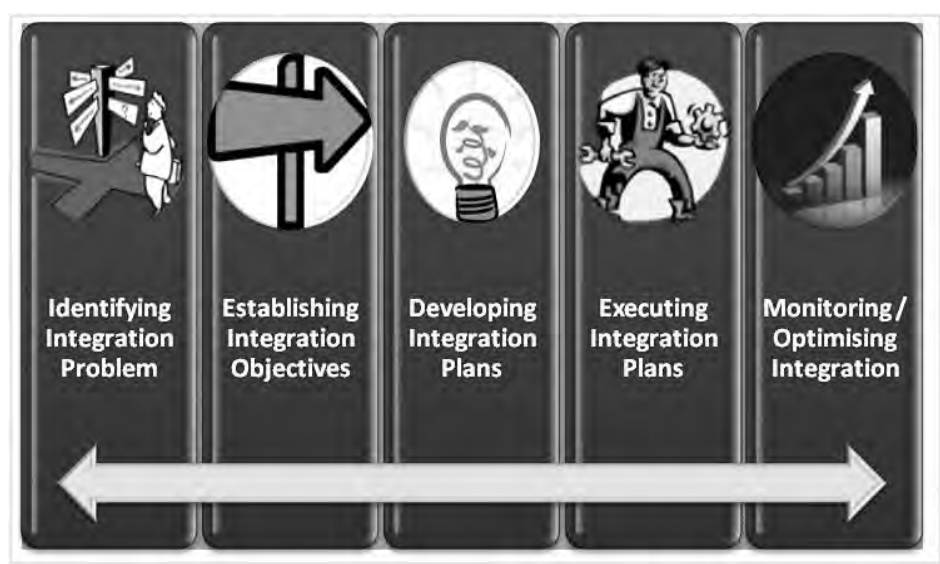

Figure 5: Improving Building Performance Framework (developed by the author)

will facilitate the provision of needed resources and the adoption of study decision. Data collection methods (i.e. literature review, survey questionnaire and interviews) and data analysis techniques (i.e. quantitative and qualitative) have to be defined and utilised. Brainstorming technique, team consensus and evaluation matrix have to be used for identifying the root causes and rank them according to their importance.

\section{Establishing integration objectives}

Towards enabling design firms and construction professionals improve building performance and adopt appropriate decisions, the objectives of integrating construction knowledge and contractor's experience in the design process have to be adequately defined and agreed by all participants. This could be achieved through using Brainstorming technique and team consensus to generate and select objectives that address the identified problem. Establishing integration objectives gives team members ownership to these objectives and encourages them to accomplish these objectives. Evaluation matrix will be used to rank these objectives according to their significance. In addition, this function will result also in defining the criteria to be used to measure the improvement of building performance.

\section{Developing integration plans}

The "Developing Integration Plans" function aims to set the procedures and actions necessary to accomplish the integration objectives. It will include a work breakdown structure and a responsibility matrix, where the first downsizes the work into manageable work packages and the later links the activity to be done and the responsible person. In addition, the plans should include expected risks and corrective actions to be taken in case of the plan did not go as planned. Furthermore, communication plan amongst project participants have to be developed to 
portray the reporting structure of the constructability review.

\section{Executing integration plans}

Within this function, the plans developed in the previous function will be executed. The execution plans may require that employees involved in the integration process be trained and equipped with all tools and technologies required to guarantee the successful execution of plans. In addition, senior management support and offering required facilities will help achieving the integration objectives. The execution stage should use the work authorization system, which provides for verification of predecessor activities and the permission to begin successor activities. This ensures the quality of work performed.

\section{Monitoring / Optimising integration}

The aim of this function is to ensure that the integration of construction knowledge and contractor's experience in the design process goes according to plan. Comments and feedback from the execution team will enable taking corrective actions if plans were not implemented as planned. Furthermore, this will help improving the performance of the construction industry in future improvement project.

\section{Limitations of the Framework}

Although the framework is theoretical and needs to be tested, it establishes the steps and set the rules that help integrating construction knowledge and contractor's experience in the design process. In addition, the effective application of the framework depends to a large extent on the willingness and encouragement of the senior management in design firms and construction companies to adopt the framework to improve building performance. On the other hand, if the senior management does not have the desire and tended not to use the framework, then its adoption will be limited. Since the adoption and application of the framework is a long-term strategy and due the tight schedules in construction projects, this framework might not be welcomed by some sectors of the industry. Due to the research limited timeframe and resources, it was not possible to apply and evaluate the framework, hence it needs to tested and validated in real construction projects.

\section{Strategies for facilitating the adoption of the framework}

In order to overcome these limitations and increase the opportunities of adopting the framework, the following strategies have to be followed:

- Escalating the awareness of architects with the importance of utilising the construction knowledge and contractor's experience towards delivering better construction projects.

- The benefits of the framework should be presented and explained to senior management of design firms in order to convince them with the role, which the framework could play in improving building performance.

- Eliminating the adversarial relationship between the different parties of the construction process through creating partnership between project team members, especially designers and contractors.

- Adopting procurement methods that encourage contractor's involvement during the design process.

- Ample time should be allowed to conduct constructability reviews as it plays a significant role towards improving building performance.

- Adopting innovative communication tools and techniques will facilitate conducting constructability reviews and archiving document for future projects.

\section{Conclusions and recommendations}

Having reviewed the nature of the construction industry, the concept of constrtactability, architecture and the design process as well as measuring building performance and keeping in mind the analysis of the case studies that benefited from integrating contractors during the design process, the research comes to the following conclusions and recommendations:

- In spite of its social and economic development contributions at national and international levels, the construction industry has a negative impact on the environment and suffers from being a fragmented business.

- The traditional procurement approaches adopted in construction projects and the different objectives, skills and interests of project participants played a significant role towards separating design from construction which ultimately hindered contractors from providing designers with their feedback and suggestions for design improvement.

- Literature review and case studies showed that the early integration of contractors in the design process, greatly improves building performance through reducing life cycle cost, compressing delivery schedules, better productivity and integrating state-of-the-art construction means and methods.

Based on these conclusions, the research recommends that:

- Design firms are advised to integrate construction knowledge and contractor's experience in the design process as an approach to improve building performance.

- Changing organisational culture and getting senior management support are essential for successful implementation of constructability concept in design firms.

- Barriers to constructability need to be identified and strategies for overcoming have to be planned, implemented and evaluated.

- Design firms are encouraged to adopt the framework developed by this research and its strategies to facilitate the integration of the constructability 
concept in the design process.

- Researchers are directed to study the integration of other project participants such as suppliers in the design stage and other stages of the project life cycle.

\section{References}

Abdellatif, M.A. and Othman, A.A.E. (2006) Improving the sustainability of low-income housing projects: The case of residential buildings in Musaffah commercial city in Abu Dhabi. Emirates Journal for Engineering Research, 11(2), 47-58.

Aeck, R.C. and Ruby, D.I. (2006) Consider Constructability", Modern Steel Construction. [Online]. Available from: www.modernsteel.com/Uploads/ Issues/../30752_lansing_web.pdf (Accessed 2 January 2010).

Anink, D., Boodtra, C. and Mark, J. (1996) Handbook of Sustainable Development. London: James and James.

Architectural Review (1995) Comment, Architectural Review, May 1995, p.4.

Arditi, D., Elhassan, A. and Toklu, Y.C. (2002) Constructability analysis in the design firm, Journal of Construction Engineering \& Management, 128 (2) 117-126.

Barrett, P. (1995) Facilities Management: Towards Best Practice. Oxford: Blackwell Science Ltd.

Burati, J.L., Farrington, J.J. and Ledbetter, W.B. (1992). Causes of quality deviations in design and construction, Journal of Construction Engineering and Management, 118 (1), 34-49.

Cascadia (2009) Cannon Beach Residence, Cascadia Region Green Building Council. [Online]. Available from: http:// casestudies.cascadiagbc.org/process. cfm?Project ID=428 (Accessed 12 June 2010).

CII (1987). Constructability Concepts File. Prepared by The Construction Industry Institute -

Constructability Task Force, Publication 3-3, Bureau of Engineering Research, The University of Texas at Austin, Austin, TX.

Douglas, E.E. and Gransberg, D.D. (2009) Implementing Project Constructability. AACE International Recommended Practice No. 30R-03. TCM Framework: 11.5 - Value Management and Value Improving Practices (VIPs). [Online]. Available from: www.aacei.org/technical/rps/30R-03.pdf (Accessed 2 January 2010).

Earth watch Institute (2011) Construction. [Online]. Available from: http://www.businessandbiodiversity.org/ construction.html (Accessed 15 November 2011).
EDMS (2007) Framework. Engineering Data Management Service. [Online]. Available from: http://cedar.web.cern.ch/CEDAR/ glossary.html\#Framework> [Accessed 2 January, 2010].

Fales, J. (1991) Construction Technology: Today and Tomorrow. 1st Ed. Peoria, Illinois: Macmillan/McGraw Hill.

Field, B. and Ofori, G. (1988) Construction and economic development: a case study, Third

World Planning Review, 10 (1), 41-50.

Hauptfleisch, A.C. and Sigle, H.M. (2004) Structural of the Built Environment in South Africa. Hatfield: CONQS-Publishers.

Home design home, Cannon Beach Residence, 2010. [Online]. Available from: http://www.homedesignhome.com/ cannon-beach-residence-by-nathan-goodarchitect-in-oregon-beach/ (Accessed 15 June 2010).

Kagioglou, M. Cooper, R. and Aouad, G. (20011) Performance management in construction: a conceptual framework, Construction Management and Economics, 19 (1), 85-95.

Langston, C.A. and Ding, G. K. C. (2001) Sustainable practices in the built environment, Langston, ButterworthHeinemann, Oxford.

Mendelsohn, R, (1997) The constructability review process: A constructor's perspective, Journal of Management in Engineering, 13 (3), 17-19.

Motsa, N., Oladapo, A. and Othman, A.A.E. (2008) The Benefits of Using Constructability during the Design Process. Proceedings of the 5 th Post Graduate Conference on Construction Industry Development, Bloemfontein, South Africa, 16 - 18 March 2008, 158-167. Mthalane D,Othman, A.A.E. and Pearl, RG. (2008) The Economic And Social Impacts Of Site Accidents on the South African Society. Proceedings of the $5^{\text {th }}$ Post Graduate Conference On Construction Industry Development, Bloemfontein, South Africa 16 - 18 March 2008, 1-10.

Nima, M.A., Abdul-Kadir, M.R. and Jaafar, M.S. (2001) Evaluation of the role of the contractor's personnel in enhancing project constructability, Structural Survey, 19(4), 193-200.

Norton B. R. and McElligott, W. C. (1995) Value Management in Construction: A Practical Guide. London: Macmillan.

O’Connor, T.J. \& Miller, S.J. (1994) Barriers to constructability implementation, Journal of Performance of Constructed Facilities, 8(2), 110-129.

Othman, A.A.E. (2007) Sustainable Architecture: an Investigation into the Architect's Social Responsibilities", in the International Conference on Sustainable Human Settlements for
Economic and Social Development, Zambezi Sun International Hotel, Livingstone, Zambia, 181-197.

Othman, A.A.E. (2008) Building the Effective Architectural Team in Design Firms: The Case of the United Arab Emirates. Emirates Journal for Engineering Research, 13 (1), 1-11.

Othman, A.A.E. and Harinarain, N. (2009) Managing Risks Associated with the JBCC (Principal Building Agreement) from the South African contractor's Perspective, Acta Stuctilia, Journal for the Physical and Development Sciences, 16 (1), 83-119.

Othman, A.A.E., Hassan, T.M. and Pasquire, C.L. Drivers for Dynamic Brief Development in Construction, Engineering, Construction and Architectural Management, 11 (4), 248-258.

Pettinger, R. (2001) Mastering Management Skills. Palgrave, New York.

Preiser, W.F.E. and Vischer, J. C. (2005) Assessing Building Performance. Elsevier Butterworth-Heinemann, Oxford OX2 8DP.

RIBA (2011) Guide to Professional Experience, RIBA Plan of Work. Royal institute of British Architects. [Onlione]. Available from:

http://www.pedr.co.uk/textpage.asp?m enu $=1$ a \& sortorder $=130 \&$ area $=$ main (Accessed 15 November 20110.

Roodman, D.M. and Lenssen, N. (1995) A Building Revolution: How Ecology Health Concerns are Transforming Construction. Paper 124 World Watch Institute, Washington, DC.

Roth, L. (1994) Understanding Architecture: Its Elements, History, and Meaning. 2nd Ed. London: The Herbert Press Ltd.

Tam V.W.Y. (2007) On prefabrication implementation for different project types and procurement methods in Hong Kong. Journal of Engineering, Design and Technology, 5(1), 68-80.

Trigunarsyah, B. (2004) A review of current practice in constructability improvement case studies on construction projects in Indonesia, Construction Management and Economics, 22(6), 567-580

Uhlik, F. T., and Lores, G. V. (1998) Assessment of constructability practices among general contractors. Journal of Architectural Engineering, 4(3), 113-123.

Wong, F.W. H.; De Saram, D. Darshi; L. P. T. I. and Chan, D. W. M. (2006) A Compendium of Buildability Issues from the Viewpoints of Construction Practitioners, Architectural Science Review, 49 (1), 81-90.

Zimmerman, L. W., and Hart, G. D. (1982) Value engineering-a practical approach for owners, designers, and contractors, Van Nostrand Reinhold, New York. 